course of preparatory work, do not necessarily imply that a state which has become a party to the convention ceases automatically to be such if it ceases to be a member of any of these organizations. The Tokyo Convention contains a denunciation clause (Art. 23) of the usual type which does not reflect Dr. Shubber's view ( $c f$. also Art. 26), but does not contain any clause concerning expulsion or automatic exclusion from the Convention of any party. Dr. Shubber, furthermore, is unable to cite any state practice or provision in the Vienna Convention on the Law of Treaties to support his position. $C f$. Articles 54 and 55 of the Vienna Convention which, though not directly applicable, rather point in the opposite direction.

\title{
To The EdrTor-IN-Chief,
}

You were kind enough to pay attention in your widely known Journal to my book Zastrzeżenia do traktatów wielostronnych ["Reservations to Multilateral Treaties"]. I refer to the book note by Professor Kazimierz Grzybowski which appeared in 70 AJIL 616-17 (1976). I admit that it is a somewhat unusual step on the part of an author of a book to comment upon a review. And if $I$ do so, it is because something more than my personal dissatisfaction is involved in the whole issue.

In my opinion, even if one chooses to present citations concerning third class problems only-as is the case with the review under consideration-at least these citations should correspond to the real text of a book. There are three quotations from my book with the respective pages indicated and to my regret not one meets this requirement.

The review says: "The author states four reasons for the innovations in the Treaty on Treaties as regards reservations, among them structural changes in the international community (the theory of the three camps) (p. 68)." In fact neither in the text nor in the context of "four reasons" given on p. 68 is an allusion made to the Treaty on Treaties. The exact translation of the whole statement in question is as follows:

B ... UN period.

During the UN period reservations grew (and continue to grow) in number in a geometrical progression. This growth is an outcome of the following facts: ... .

一....

- ....

-differentiation of the international community: existence of socialist states, capitalist states and the so-called Third World states, representing very often different group interests.

The review goes on: "However, in describing various tendencies among the participants in the Vienna Conference which drafted the text of the Convention, she discovers that the proponents of the new rules included the United States, most of the Latin American states, socialist states, and some others, a somewhat puzzling statement in view of the earlier findings (p. 143)." In fact on p. 143 no allusion in any form whatsoever is made either to the Vienna Conference or to the Treaty on Treaties. It is clear from the text as well as from the context that all references to the positions of states appearing on this page deal with the General Assembly debates on reservations to the Genocide Convention in 1950-1952. Having indicated which countries defended the idea of unanimity in respect of reservations to this Convention, I stated (p. 143): "Almost all countries from the American continent (including the USA), socialist states (except 
Yugoslavia) and certain others advocated in the General Assembly a more liberal solution." Of course, the Vienna Conference and the Vienna Convention itself, are analyzed in my book but on different pages and in a different way.

The review says: "Furthermore, she points out that, although the Soviet delegation considered the ICJ's Opinion in the Reservations to the Genocide Convention case an improper involvement of the Court in matters which were outside its jurisdiction, the Polish delegation considered it an important element in the development of new rules of international law ( $p$. 166)." In fact, having presented a concept of nonacceptance of reservations defended by socialist states in the General Assembly during the debates on reservations to the Genocide Convention, my book says the following on the views expressed in 1951 (p. 166): "It is interesting in this context that while the USSR delegate recognized the ICJ Advisory Opinion as inadequate, the delegate of Poland supported it, adding that broader consequences should be drawn from it." This is an exact translation of the whole statement in question. A comparison of these two texts discloses the significant differences, and I am something less than grateful to the reviewer for supplementing ideas presented as mine.

Whatever are the reasons behind such a treatment of the book by the reviewer, this very fact provides me with an opportunity to say something in connection with the alleged "little significance" of the book and "somewhat conventional and purely legalistic approach" although, I admit, it is an even more unusual step on the part of the author of a book. I regret very much that looking for my "ritual genuflections at the shrine of the dogma of the progressive role of the socialist camp in the development of international law" (an excerpt from the review) has prevented Professor Grzybowski from seeing and recording the fact that the materials analyzed in the book include, inter alia, an outcome of my macroscale (global) study of state practice (reservations, objections, withdrawals of reservations, reservation clauses) based on: Martens' Recueil, the LNTS, Hudson's International Legislation, the UNTS (710 volumes), and UN Doc.ST/LEG/SER.D/5. Conclusions drawn from this reexamination of state practice, often unexpected and unique in many respects, are present in all relevant paragraphs of the book (figures, classifications, typical/exceptional practices, etc.). This one could hardly find in any previous book on the subject.

Renata Szafarz University of Warsaw, Poland

\section{Professor Grzybowski responds:}

I am somewhat puzzled by Dr. Szafarz' complaint concerning page references. I have not quoted from the book, and page references are to passages and subsections which deal with matters reported in the review. Dr. Szafarz does not dispute the correctness of my summations of her argument which must per force be somewhat generalized in view of the limited space. Our other differences of opinion are the result of distance and perspective.

I am quite sure two or three books later Dr. Szafarz will see her work as not quite as perfect as it seems to her today and will perhaps realize that a reviewer for a foreign audience must meet broader criteria. I am quite sure that her dissertation is a contribution to Polish study of international law. It is not in the international context for the public which does 